\title{
PERLINDUNGAN HUKUM PIHAK KETIGA (PENYEWA) TERHADAP INVESTOR AKIBAT TIDAK MELEPASKAN HAK GUNA BANGUNAN PASCA PEMUTUSAN KONTRAK BAGI TEMPAT USAHA
}

\author{
Oleh: Rexon Manihuruk', Tri Lisiani Prihatinah, Sulistyandari
}

\begin{abstract}
Uncertainty of the status of the building rights after the termination of the contract for the place of business has an impact on third parties (tenants) who do not get certainty to who pays the lease obligations. Each party, both from the Tegal City Regional Government and the Investor claim as the right party. Even since the settlement of the peace agreement for the implementation of the Reinjection Decision Number 413/PK/Pdt/2008 (from the Investor's lawsuit against the Tegal City Government) after the termination of the contract for the place. The tenant gets uncertainty again when the Investor's lawsuit against the tenant after receiving the morning market compensation from the Tegal City Government, increasingly becomes unclear the status of the HGB for the stall occupied.

This study uses a normative juridical approach to analyze court decisions and termination of agreements and legal protection. The research specification is descriptiveanalytic and the analysis is based on secondary data.

Termination of the contract for the place of business does not necessarily mean that the status of the HGB has also been transferred. This must be done with the release of rights as regulated in Article 35 of Government Regulation Number 40 of 1996, Land Use Rights, Building Use Rights, and Land Use Rights, namely paragraph 1 (c) , in the case of the author who raised the status of the HGB above the HPL of Block $B$ and $C$ of the Tegal City Morning Market after the termination of the contract for the place of business is still on behalf of the Investor as the rights holder. Legal protection for third parties/tenants is the first repressive form of protection which is reflected in the objection ruling Decision Objection. Number 7/Pdt.G.S/2018/PN. The Tegal District Court's claim from an investor that was declared unacceptable refers to the implementation of a peace agreement between the Tegal City Government and the Investor.
\end{abstract}

Keywords: Contract, HGB, Legal Protection

\section{ABSTRAK}

Ketidakpastian status HGB pasca pemutusan kontrak bagi tempat usaha, berdampak kepada pihak ketiga (penyewa) yang tidak memperoleh kepastian kepada siapa membayar kewajiban sewa. Masing-masing pihak baik dari Pemerintah Daerah Kota Tegal maupun Investor mengklaim sebagai pihak yang berhak. Bahkan sejak terjadinya perjanjian perdamaian ganti rugi pelaksanaan Putusan Peninjuan Kembali Nomor 413/PK/Pdt/2008 (dari gugatan Investor terhadap Pemerintah Dareah Kota Tegal) pasca pemutusan kontrak bagi tempat. Penyewa mendapat ketidakpastian kembali ketika dengan adanya dari gugatan pihak Investor terhadap penyewa pasca menerima ganti rugi pasar pagi dari Pemerintah Daerah Kota Tegal, semakin menjadi tidak jelas status HGB atas kios yang ditempati.

Penelitian ini menggunakan metode pendekatan yuridis normatif untuk menganalisa putusan pengadilan dan pemutusan perjanjian serta perlindungan hukum.

\footnotetext{
${ }^{1}$ Pegawai Lawyer, Tegal
} 
Spesifikasi penelitian yaitu deskriptif analitik dan analisa didasarkan pada data sekunder.

Pemutusan kontrak bagi tempat usaha tidak secara serta merta status HGB juga beralih hal tersebut harus dilakukan pelepasan hak sebagaimana diatur dalam Pasal 35 Peraturan Pemerintah Nomor 40 Tahun 1996 Hak Guna Usaha, Hak Guna Bangunan, Dan Hak Pakai Atas Tanah yaitu pada ayat 1 (c), dalam kasus yang penulis angkat status HGB diatas HPL kios Blok B dan C Pasar Pagi Kota Tegal pasca pemutusan kontrak bagi tempat usaha masih atas nama pihak Investor sebagai pemegang hak. Perlindungan hukum bagi pihak ketiga/penyewa adalah bentuk perlindungan represif pertama yang tercermin didalam putusan keberatan Putusan Keberatan Nomor 7/Pdt.G.S/2018/PN.Tgl. Pengadilan Negeri Tegal gugatan dari investor yang dinyatakan tidak dapat diterima ada mengacu pelaksanaan perjanjian perdamaian antara Pihak Pemerintah Daerah Kota Tegal dengan Pihak Investor.

Kata Kunci: Kontrak, HGB, Perlindungan Hukum

\section{A. Pendahuluan}

Pembangunan infrastruktur merupakan aspek penting bagi daerah, adanya infrastruktur dapat membantu gerak laju pertumbuhan ekonomi bagi masyarakat. Terwujudnya pembangunan infrastruktur tidak lepas dari pembiayaan, tersedianya anggaran/dana yang merupakan elemen penting terlaksanannya pembangunan. Pembiayaan salah satu kendala yang sering dihadapi oleh daerah dalam melaksanakan pembangunan, keterbatasan anggaran dan skala prioritas penggunaan anggaran daerah menjadi hambatan terlaksananya pembangunan infrastruktur. Salah satu cara untuk menyiasati, daerah menggunausahakan barang milik daerah yang bersangkutan dalam bentuk kerjasama/kemitraan dengan

$$
\text { pihak swasta. }^{2}
$$

Salah satu bentuk kerjasama antara Pemerintah Daerah dengan Swasta diantaranya adalah Kontrak Bagi Tempat Usaha yang pengaturannya diatur pada Peraturan Menteri Dalam Negeri Nomor 3 Tahun 1986 tentang Penyertaan Modal Daerah. Pada Pihak Ketiga. Kontrak Bagi Tempat Usaha merupakan bentuk perjanjian yang diselenggarakan antara Pemerintah Daerah dengan Investor, dimana Pemerintah Daerah menyediakan sebidang tanah yang berstatus Hak Pengelolaan (HPL) dan memungkinkan untuk mendirikan tempat usaha, sedangkan untuk membangun bangunan tersebut menjadi tanggungan Investor. Dalam " Kontrak bagi tempat usaha", Pemerintah daerah

\footnotetext{
2 Y Hikmat Ginanjar, 2005, Tesis : Perjanjian Build Operate Transfer sebagai bentuk pilihan perjanjian yang paling menguntungkan pada perjanjian kerjasama antara pemerintah daerah kabupaten bogor dengan PT lestari Indah Raya Persada Dalam Pembangunan Serta Pengelolaan Pasar/ Sub Terminal Parung, Universitas Indonesia, Jakarta, HIm. 2.
} 
mendapatkan pokok prestasi berupa hak menerima bangunan tempat usaha berikut prestasi tambahan dari Investor. Prestasi tambahan ini berupa hak menerima bangunan tertentu selain bangunan tempat usaha, hak untuk mengelola atau ikut serta mengelola tempat usaha, hak untuk menarik retribusi dari para pedagang yang menempati tempat usaha, hak atas penggantian retribusi yang hilang selama masa pengerjaan bangunan, hak untuk memungut parkir pada tempat usaha tersebut. ${ }^{3}$ Kemudian ada beberapa hal catatan tentang kontrak bagi tempat usaha yaitu:

- Semua biaya penyelesaian bangunan tempat usaha dimaksud menjadi tanggung jawab pihak ketiga (Investor);

- Sebagian tempat usaha yang dibangun dimanfaatkan dan dikelola oleh swasta sedangkan sebagian lagi dimanfaatkan oleh atau ditentukan statusnya oleh Pemerintah Daerah;

- Atas bangunan yang dibangun oleh pihak ketiga tersebut diberikan sertifikat Hak Guna Bangunan (HGB) di atas HPL,

- Bangunan tersebut masuk dalam inventaris daerah;

- Kepada pihak swasta diberikan wewenang penuh untuk pengelolaan gedung tersebut seumur HGB yang diberikan;

3 B.Resti Nuhayati dan Sudikno Mertokusumo, 1996, Tinjauan Yuridis Kontrak Bagi Tempat Usaha DI Propinsi Dati I Jawa Tengah, http://ilib.ugm.ac.id/jurnal//download.php?datal d=5876, diakses 16 Januari 2019.
- Seluruh bangunan tersebut menjadi milik daerah setelah berakhirnya HGB yang bersangkutan. ${ }^{4}$

Pelaksanaan kerja sama tidak selalu berjalan lancar, terlebih ketika pihak-pihak dalam perjanjian kerja sama tidak melaksanakan kewajibannya sesuai yang disepakati hingga terjadi pemutusan sepihak. Hal tersebut selalu menimbulkan kerugian sehingga berpotensi menimbulkan permasalahan hingga terjadi sengketa di Pengadilan.

Seperti dalam pelaksanaan perjanjian kerjasama Kontrak Bagi Tempat Usaha yang terjadi guna pembangunan Pasar Pagi Kota Tegal tidak berjalan dengan lancar. Pada tahun 1991, antara Pemerintah Kota Tegal dengan Investor/ Swasta menjalin kerja sama dalam sebuah perjanjian Kontrak Bagi Tempat Usaha Pasar Pagi Kota Tegal. Perjanjian kerja sama antara Pemerintah Kota Tegal dengan Investor tersebut telah disahkan oleh Menteri Dalam Negeri, dengan demikian telah memenuhi sebagaimana yang diatur Peraturan Menteri Dalam Negeri Nomor 3 Tahun 1986 tentang penyertaan modal daerah pada pihak ketiga.

Oleh karena itu, perjanjian tersebut telah berlaku bagi kedua belah

\footnotetext{
${ }^{4}$ Wahyudi Kumotoromo, 1999, Kemitraan Usaha Sebagai Alternatif Dalam Pembiayaan Sektor Publik Di Daerah
} 
pihak. Masing-masing pihak baik dari pemerintah Kota Tegal maupun Investor telah menyertakan modalnya dalam pembangunan pasar pagi kota Tegal. Dalam perjanjian yang disepakati pihak Investor mempunyai kewajiban membangun blok $\mathrm{A}, \mathrm{B}$ dan $\mathrm{C}$ Pasar Pagi Kota Tegal. Pihak Investor sejak dibuat perjanjian tersebut diberikan HGB di atas HPL, serta diberikan hak untuk menjual dan memasarkan kios pasar pagi kota Tegal.

Pelaksanaan kontrak bagi tempat usaha Pasar Pagi Kota Tegal tidak berjalan dengan lancar. Hal ini terjadi dikarenakan pihak Investor tidak selesai melakukan pengerjaan pembangunan kios dan loos pasar pagi secara keseluruhan dari tiga blok yang seharusnya dibangun, namun hanya blok $B$ dan $C$ yang pembangunannya telah selesai dan telah dikelola sedangkan untuk blok $A$ belum selesai dikerjakan sebagaimana pihak Investor seperti yang disepakati dalam perjanjian.

Sekitar tahun 2002, Pemerintah Daerah Kota Tegal secara sepihak melakukan pemutusan kontrak bagi tempat usaha. Pemutusan tersebut dilakukan dengan pertimbangan oleh karena pihak Investor tidak dapat melaksanakan pembangunan yang mengakibatkan kerugian terhadap warga masyarakat khususnya bagi penyedia sarana kepentingan umum untuk aktifitas perdagangan. Kerugian yang ditimbulkan tidak hanya berdampak kepada warga masyarakat tetapi juga terhadap pemerintah Kota Tegal yang menyebabkan terhambatnya pembangunan kota.

Pemutusan kontrak yang dilakukan oleh Pemerintah Kota Tegal digugat pihak Investor. Hal ini terjadi karena Pemerintah Kota Tegal melakukan pemutusan secara sepihak tanpa disertai ganti rugi sehingga telah melanggar Pasal 8 Kontrak Bagi Tempat Usaha Pasar Pagi Kota Tegal Nomor 573/00882. Sengketa tersebut sampai dengan upaya peninjauan kembali dalam Putusan Peninjuan Kembali Mahkamah Agung Republik Indonesia Nomor 413PK/PDT/2008, menyatakan Pemerintah Kota Tegal telah melakukan perbuatan melawan hukum dan menghukum Pemerintah Kota Tegal untuk membayar ganti rugi kepada pihak Investor.

Pembayaran ganti rugi baru dilaksanakan setelah Pemerintah Kota Tegal dengan Pihak Investor membuat perjanjian perdamaian dan pembayaran ganti rugi pasar pagi Kota Tegal Nomor 181 /001, 181/002, 181/003 pada tahun 2015. Pihak Pemerintah Kota Tegal telah melaksanakan kewajibannya membayarkan ganti rugi senilai Rp.12.655.378.220,- (dua belas milyar enam ratus lima puluh lima juta tiga ratus tujuh puluh depalan ribu dua ratus dua puluh rupiah) kepada 
pihak Investor. Namun, pihak Investor belum menyerahkan/ melepaskan seluruh HGB atas kios-kios Blok B dan $C$ sesuai pasal 3 ayat (1) perjanjian nomor 181/003 pembayaran ganti rugi Pasar Pagi Kota Tegal.

Dampak belum dilepaskannya HGB oleh pihak Investor kepada pihak Pemerintah Kota Tegal adalah para pedagang sebagai pihak ketiga yang menyewa di kios blok B dan C diadukan oleh pihak Investor ke pihak Kepolisian. Para pedagang diadukan ke pihak kepolisian karena menempati kios tanpa membayar sewa kepada pihak Investor. Disisi lain, ternyata para pedagang tidak membayarkan kepada pihak Investor karena beberapa pedagang pernah membayarkan sewa kepada Pemerintah Kota Tegal. Selain mengadukan pedagang, pihak Investor mengajukan gugatan terhadap para pedagang secara satu per satu untuk membayarkan sewa kepada Investor atau mengosongkan kios apabila tidak membayar sewa kios yang ditempati.

$\begin{array}{crr}\text { Dalam } & \text { Putusan } & \text { Pengadilan } \\ \text { Negeri } & \text { Tegal } & \text { Nomor } \\ \text { 1/PdtG.S/2018/PN. Tgl, dan } & \text { Putusan }\end{array}$
Pengadilan Negeri Tegal Nomor 7/Pdt.G.S/2018/PN.Tgl, mengabulkan gugatan-gugatan dari pihak Investor yang dalam amarnya menyatakan para pedagang/penyewa melakukan wanprestasi dan menghukum untuk membayar sewa kepada pihak Investor,

namun salah satu pedagang mengajukan keberatan atas putusan Pengadilan Negeri Tegal Nomor 7/Pdt.G.S/2018/PN.Tgl. Pada tingkat keberatan gugatan pihak Investor dinyatakan tidak dapat diterima dengan salah satu pertimbangan hukumnya pihak Investor dinyatakan mempunyai kewajiban menyerahkan/membalik nama seluruh kios-kios blok $B$ dan $C$ kepada Pemerintah Kota Tegal.

Dari uraian diatas yang menjadi permasalahan adalah bagaimana perlindungan hukum bagi pihak ketiga (penyewa) kios pasca putusnya kontrak bagi tempat usaha. Pertanyaan penulis itu muncul oleh karena pihak Investor dalam dalil gugatan terhadap penyewa menyebutkan sebagai pemegang HGB, sehingga menurut peneliti ada persoalan kontradiksi dengan perjanjian perdamaian pembayaran ganti rugi atas Putusan Peninjuan Kembali Mahkamah Agung Republik Indonesia Nomor 413PK/PDT/2008 pasca pemutusan kontrak bagi tempat usaha. Oleh sebab itu, menurut penulis perlu diteliti bagaimana secara yuridis status pemegang $\mathrm{HGB}$ pasca pemutusan kontrak bagi temapt usaha, sehingga dapat dipastikan kewajiban penyewa untuk membayarkan sewa kepada siapa, apakah membayar sewa kepada 
pihak Investor atau kepada pihak Pemerintah Kota Tegal. Sementara kedua belah pihak merasa mempunyai hak sebagai pemegang atas $\mathrm{HGB}$ kios pasar pagi blok $B$ dan $C$, kondisi ketidakpastian status HGB terhadap kios pasar pagi blok $B$ dan $C$ pasca pemutusan kontrak bagi tempat usaha berimplikasi kepada pihak ketiga (penyewa) yang tidak memperoleh kepastian pembayaran sewa kepada siapa.

\section{B. Permasalahan}

1. Bagaimana status Hak Guna Bangunan yang diperolah atas Hak Pengelolaan pasca pemutusan Kontrak Bagi Tempat Usaha?

2. Bagaimana perlindungan hukum pihak ketiga (Penyewa) Kios Pasar Pagi terhadap Investor/pengelola pasca pemutusan Kontrak Bagi Tempat Usaha?

\section{Metode Penelitian}

Metode Pendekatan yang digunakan Yuridis Normatif, Spesifikasi Penelitian Deskriptif. Sumber Data: Data Sekunder, dengan Metode Pengumpulan Bahan Hukum: Studi Pustaka Metode Analisa secara Normatif Kualitatif.

\section{Hasil Penelitian dan}

\section{Status Hak Guna Bangunan}

yang diperoleh diatas Hak Pengelolaan pasca pemutusan Kontrak Bagi Tempat Usaha Pasar Pagi Kota Tegal

Kontrak bagi tempat usaha merupakan perjanjian kerjasama antara pemerintah daerah dengan investor untuk membangun atau membangun kembali suatu bangunan tempat usaha, dimana pihak Pemerintah daerah menyediakan sebidang tanah yang berstatus Hak Pengelolaan (HPL) yang memungkinkan mendirikan tempat usaha, sedangkan biaya untuk membangun tempat usaha tersebut disediakan investor. Diatas tanah HPL tersebut diberikan Hak Guna Bangunan (HGB) atas nama investor dan/ atau oleh Pemerintah Daerah, dan setelah masa perjanjian selesai bangunan berikut fasilitas yang melekat pada bangunan tersebut diserahkan kepada Pemerintah Daerah. ${ }^{5}$

Pengaturan mengenai kontrak bagi tempat usaha diatur pada Peraturan Menteri Dalam Negeri Nomor 3 Tahun 1986 tentang Penyertaan Modal Daerah pada Pihak Ketiga (Peraturan tersebut telah dicabut), jadi para prinsinpya

\footnotetext{
5 B.Resti Nurhayati dan Sudikno Mertokusumo, 1996, Tinjauan Yuridis "Kontrak Bagi Tempat Usaha" Di Propinsi Dati I Jawa Tengah", BPPS- UGM, Yogyakarta, HIm. 399
} 
kontrak bagi tempat usaha merupakan perjanjian mengenai pembangunan/ pemborongan dan pengelolaan, bila saat ini perjanjian kerjasama kontrak bagi tempat usaha mempunyai kesamaan dengan perjanjian bangun guna serah (build operate transfer) namun dalam kontrak bagi tempat usaha pemerintah daerah dapat mengelola bersama (sebagian). Dalam hal ini penulis akan membahas bagaimana status HGB diatas HPL bila terjadi pemutusan sepihak kontrak bagi tempat usaha seperti yang terjadi dalam sengketa mengenai pemutusan sepihak Kontrak Bagi Tempat Usaha Pembangunan Pasar Pagi Kota Tegal.

Berdasarkan data hasil penelitian Pemerintah Daerah Kota Tegal dan Investor/PT Sinar Permai telah mengikatkan diri dalam perjanjian kerjasama yaitu perjanjian Kontrak Bagi Tempat Usaha Pasar Pagi Kota Tegal Nomor 573/00882, dimana dalam perjanjian yang dibuat kedua belah pihak telah lahir adanya hak dan kewajiban masingmasing para pihak, dari data tersebut berarti terjadi peristiwa yang dengan Pasal 1313 Kitab Undang-Undang Hukum Perdata adalah suatu perbuatan dimana satu orang atau lebih mengikatkan dirinya terhadap satu orang lainya atau lebih. Kemudian menurut Sudikno Mertokusumo, perjanjian adalah hubungan hukum antara dua pihak yang menimbulkan hak dan kewajiban atas suatu prestasi. Dengan demikian hak dan kewajiban yang diperjanjian tersebut haruslah dipenuhi oleh Pemerintah Daerah Kota Tegal.

Kontrak Bagi Tempat Usaha Pasar Pagi Kota Tegal Nomor 573/00882 yang dibuat antara Pemerintah Daerah Kota Tegal dengan PT Sinar Permai mengenai pembangunan kembali Pasar Pagi Kota Tegal dan Pengelolaan selama 30 (tiga puluh) Tahun, PT Sinar Permai diberikan HGB diatas HPL selama 30 Tahun. Setelah perjanjian tersebut berakhir bangunan tersebut menjadi milik pemerintah daerah Kota Tegal. Pada dasarnya dalam $\mathrm{KUH}$ Perdata tidak mengatur secara khusus mengenai Perjanjian/ Kontrak Bagi Tempat Usaha, Kontrak Bagi Tempat Usaha dengan dasar Peraturan Menteri Dalam Negeri Nomor 3 Tahun 1986 tentang penyertaan modal daerah pada pihak ketiga (Peraturan tersebut telah dicabut). Bahwa sebagaimana diuraikan 


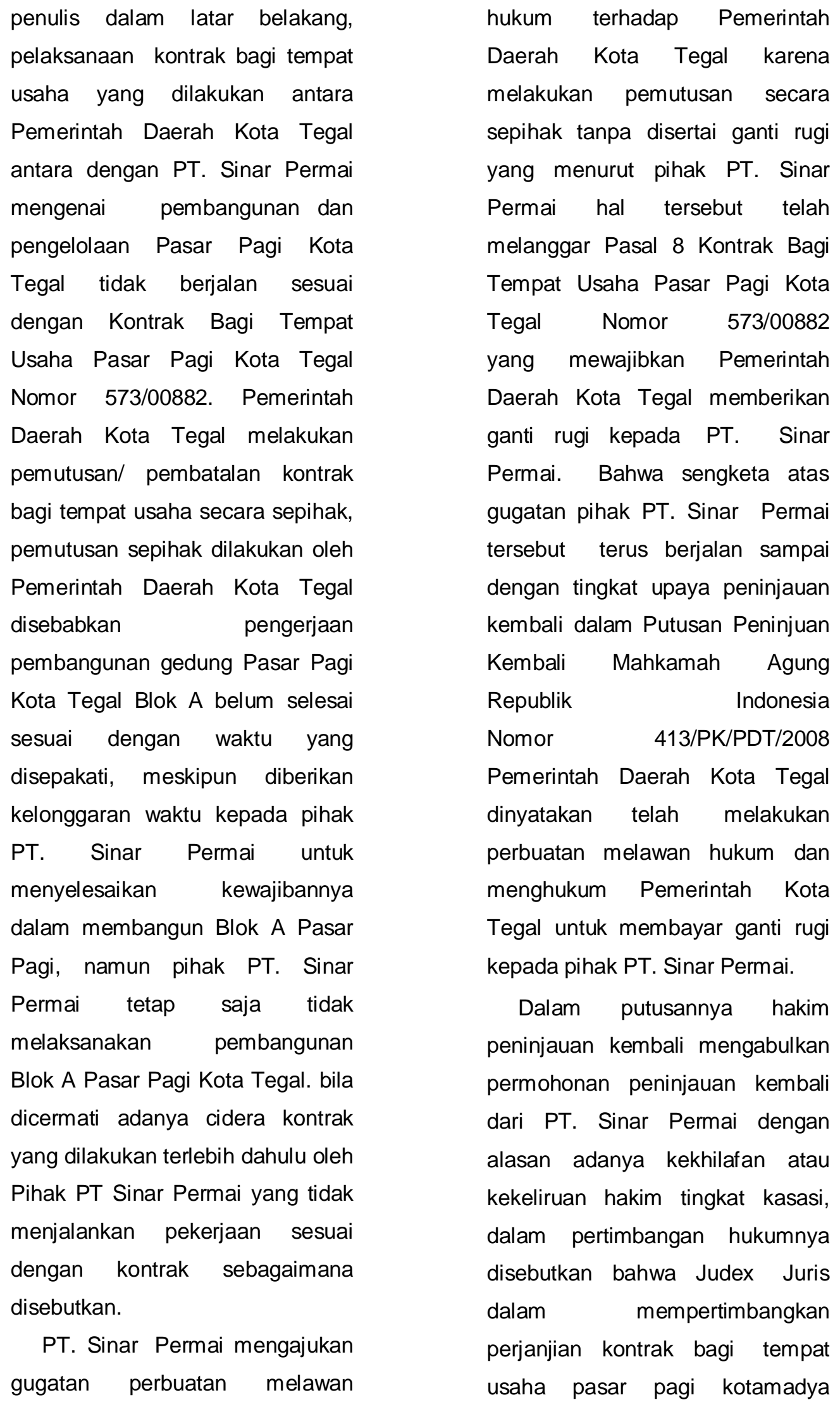


daerah tingkat II Tegal No. 573/00882 tanggal 5 Maret 1991 terutama Pasal 8 telah melakukan kekeliruan, menurut perjanjian tersebut kalau terjadi pengalihan pembangunan kios dan loos pasar kepada pihak lain, maka pihak kedua dalam hal ini Penggugat berhak mendapat ganti rugi. Dalam amar putusannya hakim peninjauan kembali menyatakan Pemerintah Kota Tegal telah melakukan perbuatan melawan hukum dan menghukum Tergugat untuk membayar ganti rugi kepada Penggugat sebesar Rp.5.526.049.519,- (lima milyar lima ratus dua puluh enam juta empat puluh sembilan ribu lima ratus sembilan belas rupiah) ditambah bunga sebesar $6 \%$ untuk satu tahun dan sebesar $\mathrm{Rp}$. 111.090.000,- (seratus sebelas juta sembilan puluh ribu juta) ditambah bunga $6 \%$ per tahun masing- masing terhitung sejak tanggal 1 Desember 1993 sampai ganti rugi dibayar lunas. Penulis berpendapat bahwa putusan peninjuan kembali yang membatalkan putusan tingkat kasasi mengenai amar yang menyatakan sah pembatalan perjanjian Kontrak Bagi Tempat Usaha Pasar Pagi Kotamadya Daerah Tingkat II Tegal
Nomor: 573/00882 tanggal 5 Maret 1991 antara Pemerintah Daerah Kota Tegal dengan PT. Sinar Permai Tegal dalam surat Nomor: 5112/00127/2002 tanggal 21 November 2002 bertentangan dengan Pasal 8 Perjanjian Kontrak Bagi Tempat Usaha. Pasal 8 Kontrak Bagi Tempat Usaha Pasar Pagi Kotamadya Daerah Tingkat II Tegal Nomor 573/00882 disebutkan sebagai berikut:

1) Apabila PIHAK KEDUA tidak dapat menyelesaikan pembangunan kios dan loos Pasar Pagi Kotamadya Daerah Tingkat II Tegal dalam batas waktu sebagaimana dimaksud Pasal 7 Perjanjian ini PIHAK KEDUA dilaksanakan denda keterlambatan sebesar $R p$ 100.000,- (seratus ribu rupiah) untuk setiap hari keterlambatan.

2) Apabila PIHAK KEDUA tidak dapat melaksanakan ketentuan ayat (1) pasal ini maka PIHAK PERTAMA dapat membatalkan secara sepihak tanpa perantara pengadilan.

3) Dalam hal terjadi pembatalan secara sepihak sebagaimana dimaksud ayat (2) pasal ini semua banunan dan sarana pendukungnya yang telah ada tetap menjadi milik PIHAK PERTAMA. 
4) Pihak lain yang ditunjuk PIHAK

PERTAMA dan sanggup melanjutkan pembangunan pasar pagi sebagaimana dimaksud Pasal 3 dan Pasal 4 Perjanjian ini, wajib memberikan ganti rugi kepada PIHAK KEDUA sebesar nilai Investasi yang telah ditanamkan oleh PIHAK KEDUA, dengan terlebih dahulu dilakukan penilaian oleh Tim yang terdiri dari unsur-unsur Pemerintah Daerah terkait, PIHAK KEDUA dan bilamana diperlukan dengan memakai Jasa Konsultan dibidangnya.

5) Pembangunan baru dapat dilanjutkan setelah ganti rugi sebagaimana dimaksud ayat (4) Pasal ini dapat diselesaikan.

Pemutusan kontrak sepihak oleh Pemerintah Kota Tegal merupakan hak yang diberikan didalam ayat (2) Pasal 8 Kontrak Bagi Tempat Usaha Pasar Pagi Kotamadya Daerah Tingkat II Tegal Nomor: 573/00882, namun ada kewajiban ayat 4 yaitu memberikan ganti rugi kepada PT. Sinar Permai. Pihak Pemerintah Daerah Kota Tegal belum melaksanakan kewajibannya yaitu memberikan ganti rugi kepada PT Sinar Permai, jadi dengan tidak diberikannya ganti rugi oleh Pemerintah Daerah Kota Tegal jelas merupakan wanprestasi (pelanggaran) terhadap ayat 4 Bagi Tempat Usaha Pasar Pagi Kotamadya Daerah Tingkat ॥ Tegal Kotamadya Daerah Tingkat II Tegal Nomor: 573/00882. Namun demikian, menurut penulis meskipun majelis hakim peninjuan kembali membatalkan putusan tingkat kasasi, tetapi mengabulkan tuntutan ganti rugi dari PT. Sinar Permai hal tersebut merupakan pelaksanaan pemutusan kontrak tersebut bila merujuk pada pasal 8 ayat 1 - 5 saling berhubungan bila terjadi pemutusan dan pengalihan pembangunan PT. Sinar Permai berhak memperoleh ganti rugi.

Bahwa mengenai pengaturan pemutusan/ pembatalan sebuah kontrak pada prinsipnya diatur dalam KUH Perdata 1266 disebutkan bahwa "Syarat batal dianggap selalu dicantumkan dalam persetujuan yang timbal balik, andaikata salah satu pihak tidak memenuhi kewajibannya. Dalam hal demikian persetujuan tidak batal demi hukum, tetapi pembatalan harus dimintakan kepada Pengadilan." Sebagaimana menurut $R$ Subekti mengenai pembatalan secara sepihak "para pihak yang 


\begin{abstract}
berkontrak dapat juga mengadakan ketentuan agar pembatalan ini tidak perlu diucapkan oleh hakim, sehingga perjanjian dengan sendirinya akan terhapus apabila salah satu pihak tidak memenuhi kewajibannya". ${ }^{\circ}$
\end{abstract}

Menurut Munir Fuady, pemutusan perjanjian berdasarkan Pasal 1266 tersebut menjadi permasalahan hukum, apabila dilakukan terhadap suatu perjanjian pemborongan, sebab dalam praktiknya menurut Munir Fuady pelaksanaan pembatalan melalui pengadilan harus ditempuh lewat prosedur gugatan biasa yang sangat panjang, berbelit dan melelahkan karna tidak adanya prosedur khusus untuk pembatalan suatu kontrak oleh Pengadilan. Akibatnya ketentuan ini dalam praktiknya malah merugikan semua pihak. $^{7}$ Selain itu, berdasarkanPasal $1611 \mathrm{KUH}$ Perdata bagi pihak yang memborongkan dalam perjanjian pemborongan diberikan hak untuk memutus kontrak ditengah jalan kendatipun hal tersebut tidak ditentukan dalam perjanjiannya. Namun untuk itu, pihak yang

\footnotetext{
${ }^{6}$ Subekti, 2003, Pokok-pokok Hukum Perdata, Intermasa, Jakarta, HIm.148 ${ }^{7}$ Munir Fuady, 2001, Hukum Kontrak (Dari Sudut Padang Hukum Bisnis), PT Citra Aditya, Bandung, HIm. 9
}

memborongkan harus memberikan penggantian kerugian terhadap pemborong, meliputi biaya yang telah dikeluarkan dan keuntungan yang hilang memutuskan kontrak secara sepihak hanya kepada bouwheer, dengan pertimbangan atau dikarenakan pihak bouwheer akan mengalami masalah yang lebih besar, apabila suatu pekerjaan konstruksi menjadi terbengkalai. $^{8} \quad$ Penyimpangan permohonan pembatalan kontrak melalui putusan pengadilan sangat dimungkinkan, mengingat hukum perjanjian menganut sistem terbuka karena segala hal dapat dituangkan dalam perjanjian merupakan hukum bagi para pihak sebagaimana asas pacta sunt servanda yang terkandung didalam Pasal 1338 KUH Perdata yang mengatur bahwa "semua perjanjian yang dibuat secara sah berlaku sebagai undang-undang yang mengatur bagi mereka yang membuatnnya". Pada hakikatnya pembatalan perjanjian (kontrak) tanpa melalui pengadilan tidak diatur tegas dalam KUH Perdata, namun secara implisit dalam pasal 1611 KUH Perdata memperkenankan pemutusan sepihak persetujuan

\footnotetext{
${ }^{8} \mathrm{Ibid}, \mathrm{HIm} .29$
} 


\begin{abstract}
pemborongan dengan syarat memberikan ganti rugi kepada pihak yang diputus. Bila dihubungkan pemutusan sepihak kontrak bagi tempat usaha oleh Pemerintah Daerah Kota Tegal pada dasarnya diperkenankan, namun Pemerintah Daerah Kota Tegal wajib memberikan ganti rugi kepada pihak PT Sinar Permai. Jadi menurut penulis mengenai pemutusan perjanjian sepanjang diatur para pihak didalam perjanjian sudah seharusnya dihormati, karena hal tersebut telah disepakati sebagaimana asas pacta sunt servanda yang terkandung dalam $1338 \mathrm{KUH}$ Perdata.
\end{abstract}

Bahwa sengketa antara PT. Sinar Permai dengan Pemerintah Daerah Kota Tegal akibat pemutusan secara sepihak tanpa disertai ganti rugi yang terjadi hingga Putusan Peninjuan Kembali Mahkamah Agung Republik Indonesia Nomor 413/PK/PDT/2008, dilaksanakan dengan perjanjian perdamaian dan pembayaran ganti rugi Pasar Pagi Kota Tegal Nomor 181/001 Jo Perjanjian Nomor 181/002 Jo Perjanjian Nomor 181/003. Menurut penulis perjanjian perdamaian tersebut adalah sebagai penyempurnaan pelaksanaan pasca pemutusan kontrak bagi tempat usaha Pasar Pagi Kota Tegal, oleh karena disebutkan dalam Perjanjian Nomor 181/003 Perubahan Perjanjian Pembayaran Ganti Rugi Nomor: 181/ 002 antara PT. Sinar Permai dengan Pemerintah Kota Tegal tentang Pembayaran Ganti Rugi Pasar Pagi Kota Tegal pada pasal 3 disebutkan bahwa kewajiban PT Sinar Permai:

1. Sejak pembayaran Ganti Rugi Pokok Pasar Pagi tahun 2015, maka Pihak Pertama (PT Sinar Permai) menyerahkan dan membaliknama seluruh kioskios Blok B dan Blok $C$ yang Hak Guna Bangunan-nya (HGB-nya) masih atas nama pihak Pertama kepada pihak kedua (Pemerintah Daerah Kota Tegal) secara utuh.

2. Pihak pertama (PT Sinar Permai) diberikan kesempatan untuk menyewa kios-kios Blok B dan Blok C Pasar Pagi Kota Tegal melalui perjanjian yang akan dibuat oleh Para Pihak.

3. Pihak Pertama (PT Sinar Permai) wajib membayar Sewa dan Retribusi kioskios Blok B dan blok C Pasar Pagi Kota Tegal sesuai dengan ketentuan Peraturan Perundang- 
Undangan yang berlaku.

Secara implisit perjanjian tersebut mempunyai maksud yang sama sebagaimana dalam ayat 3 dan 4.Pasal 8 Kontrak Bagi Tempat Usaha Pasar Pagi Kotamadya Daerah Tingkat II Tegal Nomor: 573/00882 yang harus dilakasanakan para pihak bila terjadi pemutusan/pembatalan.

Perjanjian perdamaian diatur dalam Pasal 1851 KUH Perdata disebutkan bahwa perdamaian adalah suatu perjanjian dengan kedua belah pihak, dengan menyerahkan atau menahan suatu barang, mengakhiri suatu perkara yang sedang bergantung atau pun mencegah timbulnya suatu perkara. Perjanjian ini tidaklah sah, melainkan jika dibuat secara tertulis. Menurut penulis, dengan adanya perjanjian perdamaian yang dilakukan antara Pemerintah Daerah Kota Tegal dengan PT. Sinar Permai merupakan penyempurnaan pemutusan kontrak bagi tempat usaha oleh karena isi perjanjian tersebut subtansinya adalah Pihak PT. Sinar Permai menerima ganti rugi dari Pemerintah Daerah Kota Tegal, sedangkan Pemerintah Daerah Kota Tegal menerima seluruh sertifikat HGB kios Blok B dan Blok C Pasar Pagi Kota Tegal.

Jadi seharusnya seluruh kios- kios Blok B dan C Pasar Pagi Kota Tegal telah beralih kepada Pemerintah Daerah Kota Tegal, hal itu sejalan dengan karakteristik perjanjian kerjasama mengenai pembangunan dan pengelolaan ketika berakhir jangka waktu perjanjiannya, bangunan berikut fasilitas yang melekat pada bangunan tersebut diserahkan kepada Pemerintah Daerah.

Dalam hal kasus yang diangkat penulis pemutusan perjanjian kerjasama kontrak bagi tempat usaha yang kemudian lahir perjanjian perdamaian pembayaran ganti rugi Pasar Pagi Kota Tegal sebagai pelaksanaan atas putusan Peninjuan Kembali Mahkamah Agung Republik Indonesia Nomor 413PK/PDT/2008 pasca pemutusan kontrak bagi tempat usaha seharusnya status HGB kios Blok $B$ dan Blok C segera beralih kepada Pemerintah Daerah Kota Tegal sebagai pemegang hak yang baru, namun hal tersebut tidak dapat langsung beralih karena terlebih dahulu adanya penghapusan HGB atas kios- kios Blok B dan C Pasar Pagi Kota Tegal yang masih atas nama PT Sinar Permai. Bahwa pengaturan mengenai penghapusan HGB diatur di dalam Pasal 40 UndangUndang Pokok Agraria, 
menentukan bahwa disebutkan disana, Hak Guna Bangunan hapus karena:

a. Jangka waktunya berakhir;

b. waktunya berakhir karena sesuatu syarat tidak dipenuhi;

c. Dilepaskan oleh pemegang haknya sebelum jangka waktunya berakhir;

d. Dicabut untuk kepentingan umum;

e. Ditelantarkan;

f. Tanahnya musnah;

g. ketentuan dalam Pasal 36 ayat (2)

Hapusnya Hak Guna Bangunan

Pasal 35 juga diatur didalam

Peraturan Pemerintah Nomor 40

Tahun 1996 Hak Guna Usaha, Hak Guna Bangunan, Dan Hak Pakai Atas Tanah, disebutkan bahwa:

(1) Hak Guna Bangunan hapus karena:

a. berakhirnya jangka waktu sebagaimana ditetapkan dalam keputusan pemberian atau perpanjangannya atau dalam perjanjian pemberiannya;

b. dibatalkan oleh pejabat yang berwenang, pemegang Hak Pengelolaan atau pemegang Hak Milik sebelum jangka waktunya berakhir, karena:

1) Tidak dipenuhinya kewajiban-kewajiban pemegang hak dan/ atau dilanggarnya

ketentuanketentuan

sebagaimana dimaksud dalam Pasal 30, Pasal 31 dan Pasal 32; atau

2) Tidak dipenuhinya syarat-syarat atau kewajiban-kewajiban yang tertuang dalam perjanjian pemberian Hak Guna Bangunan antara pemegang Hak Guna Bangunan dan pemegang Hak Milik atau perjanjian penggunaan tanah Hak Pengelolaan; atau

3) Putusan pengadilan yang telah mempunyai kekuatan hukum yang tetap;

c. Dilepaskan secara sukarela oleh pemegang haknya sebelum jangka waktu berakhir;

d. Dicabut berdasarkan Undang- Undang Nomor 20 Tahun 1961;

e. Ditelantarkan;

f. Tanahnya musnah;

g. Ketentuan Pasal 20 ayat (2).

(2) Ketentuan lebih lanjut mengenai hapusnya Hak Guna Bangunan sebagaimana dimaksud dalam ayat (1) diatur dengan Keputusan Presiden. 
Bila merujuk pada pasal tersebut diatas dihubungkan dengan isi perjanjian perdamaian seharusnya dilakukan pelepasan HGB kios-kios Blok B dan Blok C Pasar Pagi Kota Tegal yang masih atas nama PT Sinar Permai agar dapat beralih menjadi milik Pemerintah Daerah Kota Tegal. Bahwa pengertian menurut Undang-Undang Nomor 2 Tahun 2012 tentang Pengadaan Tanah Bagi Pembangunan Pembangunan Untuk Kepentingan Umum disebutkan didalam Pasal 1 ayat 1 yaitu Pelepasan Hak adalah kegiatan pemutusan hubungan hukum dari pihak yang berhak kepada negara melalui Lembaga Pertanahan. Menurut Mudakir Iskandar Syah, Pembebasan Tanah adalah pelepasan hubungan hukum antara sebidang tanah hak dengan pemiliknya, yang dilaksanakan melalui musyawarah yang selanjutnya disertai pemberian imbalan yang layak. Proses pelepasan hak dibuktikan dengan akta pelepasan hak/surat pernyataan pelepasan hak. Hal yang perlu diperhatikan setelah proses pembebasan/pelepasan hak dilakukan calon pemegang hak wajib melaksanakan permohonan kepada Negara. ${ }^{9} \quad$ Dengan adanya pelepasan hak, maka tanah yang bersangkutan menjadi tanah negara.

9

http://repository.uma.ac.id/bitstream/134 $\underline{56789 / 1537 / 5 / 088400236 \text { file5.pdf }}$
Pihak yang memerlukan tanah tersebut dapat mengajukan permohonan hak atas tanah yang baru ke Kantor Pertanahan setempat sesuai ketentuan undang- undang dan sesuai keperluannya dengan menggunakan alas hak akta pelepasan hak. Sehingga pihak yang bersangkutan mendapatkan hak atas tanah sesuai ketentuan undangundang dan sesuai keperluannya. ${ }^{10}$ Dengan demikian pelepasan/ pembebasan adalah perbuatan memutuskan haknya yang dipegang/ dimiliki dengan akta pelepasan hak. Bahwa dengan adanya gugatan terhadap para penyewa sebagaimana dalil gugatan PT. Sinar Permai menyebutkan sebagai pemegang HGB atas kios pasar pagi yang berada di Blok B maupun $C$ dalam perkara nomor Putusan Pengadilan Negeri Tegal Nomor 1/Pdt.G.S/2018/PN.Tgl dan Putusan Nomor 7/Pdt.G.S/2018/PN.Tgl. dapat penulis simpulkan PT Sinar Permai belum melepaskan HGB atas kios blok $\mathrm{B}$ dan $\mathrm{C}$ Pasar Pagi Kota Tegal yang ditempati penyewa.

Berdasarkan uraian diatas, status HGB atas kios-kios Blok B dan C Pasar Pagi Kota Tegal masih

\footnotetext{
10 Dwi Heny Ratnawati, Djauhari, 2018, Jurnal Akta Vol 5 No 1 Maret :Pelaksanaan Akta Pelepasan Hak Sebagai Alas Hak Untuk Mengajukan Permohonan Peralihan Dan PerubahanHak Guna Bangunan Yang Jangka Waktunya Telah Berakhir Di Kabupaten Brebes, HIm.6
} 
berada pada pihak PT. Sinar Permai selaku pemegang hak karena belum ada pelepasan hak, tidak dapat beralih seketika kepada Pemerintah Daerah Kota Tegal bila tidak ada akta pelepasan dari pihak PT. Sinar Permai.

2. Perlindungan hukum pihak ketiga (Penyewa) Kios Pasar Pagi terhadap Investor/pengelola pasca pemutusan Kontrak Bagi Tempat Usaha Pasar Pagi Kota Tegal

Asasi Manusia. Karena menurut sejarah dari barat, lahirnya konsep-konsep tentang pengakuan dan perlindungan terhadap hak asasi manusia, diarahkan kepada pembatasanpembatasan dan peletakan kewajiban masyarakat dan pemerintah. Prinsip kedua yang membatasi tindakan pemerintah adalah prinsip negara hukum. Dikaitkan dengan pengakuan dan perlindungan terhadap hak asasi manusia, pengakuan dan perlindungan terhadap hak asasi manusia menjadi tempat yang utama dan merupakan tujuan dari negara hukum.

Terkait rumusan masalah kedua terhadap perlindungan hukum penyewa dengan adanya persoalan yang dihadapi para penyewa yaitu ketidakpastian kepada siapa mereka membayarkan uang sewa atas kios ditempati pasca pemutusan kontrak bagi tempat usaha, karena pada awal menempati kios para penyewa membayarkan uang sewa kepada PT. Sinar Permai, namun kemudian para penyewa membayarkan kepada Pemerintah Daerah Kota Tegal yang didasari dari Surat Pemberitahuan dari Pemerintah Daerah Kota Tegal. Pada tahun 2018 para penyewa menghadapi gugatan dari pihak PT Sinar Permai yang pada pokoknya adalah sebagai pemilik kios/ pemegang HGB atas kios yang ditempati. Bahwa dalam gugatannya pihak PT Sinar Permai menuntut uang sewa kepada penghuni (penyewa) serta mengosongkan siapa saja yang menempati kios untuk segera mengosongkan tanpa syarat. Oleh sebab, itu penulis membahas persoalan tersebut pada rumusan masalah yang kedua ini.

Berdasarkan Putusan Pengadilan Negeri Tegal Nomor 1/ Pdt.G.S/2018/PN.Tgl dan Putusan Nomor 7/Pdt.G.S/2018/PN.Tgl, majelis hakim mengabulkan gugatan dari PT. Sinar Permai selaku Penggugat terhadap masing- masing Tergugat diantaranya yang dialami oleh Talan dan Rikardus Chrisanto Adhitomo selaku para penyewa kios. Bahwa dalam amar putusannya majelis hakim menyatakan penyewa 
bernama Talan dan Rikardus telah melakukan wanprestasi dengan tidak membayarkan uang sewa kios, menghukum untuk membayarkan sewa kios kepada PT. Sinar Permai dari 2003 s/d 2017 dan menghukum Tergugat atau siapa saja yang menempati Kios Pasar Pagi tersebut untuk segera mengosongkan tanpa syarat.

Bahwa terhadap Putusan

Pengadilan Negeri Tegal Nomor7/Pdt.G.S/2018/PN.Tgl, penyewa bernama Rikardus Chrisanto Adhitomo selaku penyewa kios Blok B.10 melakukan upaya hukum keberatan terhadap putusan tersebut, dengan poin alasan permohonan keberatannya adalah gugatan Penggugat (PT Sinar Permai) dikategorikan sebagai Gugatan Sederhana, karena ada persoalan hakiki terhadap seluruh kios-kios blok B dan C yaitu kewajiban Penggugat untuk mengembalikan kios-kios blok $B$ dan C Pasar Pagi kepada Kota Tegal (Pemerintah Kota Tegal), atas permohonan keberatan tersebut majelis hakim tingkat keberatan mengabulkan permohonan keberatan dari Pemohon (Rikardus Chrisanto Adhitomo) yang dalam amar putusannya menyatakan gugatan Penggugat (PT. Sinar Permai) tidak bersifat sederhana sehingga tidak dapat diterima.

Selanjutnya dimana perlindungan hukum terhadap permalasahan yang dihadapi penyewa, merujuk pada pendapatnya $M$ Hadjon langkah melalui upaya peradilan merupakan fungsi terakhir dengan sifat represif, fungsi ini dilakukan apabila tidak menemukan jalan penyelesaian akhir. Dihubungkan dengan Putusan Keberatan Nomor 7/Pdt.G.S/2018/PN.Tgl., $\quad$ yang menyatakan gugatan PT. Sinar Permai tidak dapat diterima, merupakan bentuk perlindungan hukum represif meskipun amar putusan tersebut adalah mengenai proses tata cara penyelesaian gugatan perkara sederhana, namun menurut penulis yang perlu digaris bawahi alasan/ pertimbangan hakim yang menyatakan tidak diterima adalah mengacu pada perjanjian perdamaian disebutkan didalam pertimbangannya sebagai berikut:

1. Menimbang, oleh karena ada masalah hukum di dalam pelaksanaan perjanjian perdamaiana Nomor 181/003, tertanggal 12 Oktober 2015, yaitu:

1) Termohon keberatan haruslah telah menyerahkan dan membalik namakan seluruh kios-kios blok $\mathrm{B}$ dan blok $\mathrm{C}$ 
yang Hak Guna Bangunannya (HGBnya) masih atasnama Termohon Keberatan, diberikan kepada Pihak Pemerintah Kota Tegal secara utuh; dan

2) Terdapatnya perjanjian antara termohon keberatan dengan pihak Pemerintah Kota Tegal untuk memberikan kesempatan kepada pihak termohon keberatan menyewa kios-kios Blok B dan Blok C Pasar Pagi Kota Tegal.

2. Menimbang, bahwa oleh karenanya Pemohon Keberatan telah dapat membuktikan dalil keberatannya, bahwa terdapat persoalan hakiki terhadap seluruh kios-kios Blok B dan Blok C yaitu kewajiban Penggugat atau Termohon Keberatan untuk mengembalikan kios-kios Blok B dan Blok C Pasar Pagi kepada Kota Tegal;

3. Menimbang, bahwa terhadap dalil bantahan dari termohon keberatan, sudahlah dapat dijawab berdasarkan pertimbangan di atas, bahwa pihak pemerintah Kota Tegal adalah pihak yang terikat dengan pihak Termohon Keberatan di dalam perjanjian181/003, tertanggal 12 Oktober 2015, namun oleh karena pemohon keberatan adalah salah satu penyewa dari kios Blok B sebagaimana yang diatur dalam perjanjian aquo, oleh karenanya terdapat hubungan hukum antara termohon keberatan dengan Pihak Walikota terkait pelaksanaan perjanjian aquo dan keduanya dengan Pemohon Keberatan sebagai Penyewa Kios Blok B;

4. Bahwa oleh karenanya dari awal Pemerintah Kota Tegal haruslah ditarik sebagai pihak oleh penggugat atau termohon keberatan untuk membuktikan kepentingannya.

5. Menimbang, bahwa oleh karena masih ada masalah hukum di dalam pelaksanaan perjanjian perdamaian nomor 181/003, tertanggal 12 Oktober 2015 dan pihak Pemerintah Kota Tegal haruslah ditarik sebagai pihak oleh karenanya gugatan penggugat tidaklah memenuhi Pasal 1 point 1 , Pasal 2 dan Pasal 3 Perma Nomor 2 tahun 2015 tentang tata cara penyelesaian gugatan sederhana, sehingga dari awal gugatan aquo haruslah dinyatakan tidak dapat diterima, oleh karenanya petitum ke-2 haruslah dikabulkan.

Bahwa dari pertimbangan hakim dalam Putusan Keberatan Nomor 7/Pdt.G.S/2018/PN.Tgl. Pengadilan Negeri Tegal tersebut merupakan salah satu bentuk 
perlindungan hukum represif pertama karena secara tidak langsung yangpertimbangan hakim mengacu pada perjanjian perdamaian yang dibuat antara Pemerintah Daerah Kota Tegal dan PT Sinar Permai. Namun demikian, diperlukan perlindungan hukum represif kedua yakni langkah dari Pemerintah.Pemerintah kota Tegaluntuk mengajukan mengajukan gugatan agar PT. Sinar Permai melaksanakan kewajibannya menyerahkan dan membalik nama seluruh kios blok B dan C Pasar Pagi Kota Tegal sebagai bentuk perlindungan hukum kepada para pedagang sebagai pihak ketiga berstatus sewa yang menghadapi gugatan dan mendapat pengaduan dari pihak PT. Sinar Permai kepada kepolisian agar pedagang membayarkan sewa termasuk perlindungan terhadap dampak pelaksanaan pengosongan kios sebagaimana dalam Putusan Pengadilan Negeri Tegal Nomor 1/Pdt.G.S/2018/PN.Tgl, karena pihak PT. Sinar Permai masih melakukan klaim sebagai pemilik/ pengelola atas sebagaian kios-kios blok B dan C Pasar Pagi Kota Tegal, atau setidak-tidaknya langkah hukum dengan mengajukan gugatan oleh Pemerintah Kota Tegal untuk memastikan mengenai hak sewa atas kios-kios blok B dan C Pasar Pagi Kota Tegal.

Berdasarkan hal tersebut diatas perlindungan hukum terhadap pihak ketiga/ penyewa tercermin didalam Putusan Keberatan Nomor 7/Pdt.G.S/2018/PN.Tgl. Pengadilan Negeri Tegal yang menyatakan gugatan Investor (PT Sinar Permai) tidak dapat diterima. Namun demikian, untuk menyelesaikan persoalan tersebut secara perlu ada langkah Pemerintah Daerah Kota Tegal sebagai pihak yang berkaitan untuk mengajukan gugatan agar menyerahkan HGB yang masih dipegang oleh PT. Sinar Permai dan memastikan hak sewa atas kios-kios yang ditempati penyewa yang belum dibayarkan.

\section{E. Penutup}

\section{Kesimpulan}

Berdasarkan analisis penulis terhadap hasil penelitian diperoleh simpulan sebagai berikut:

a. Pemutusan kontrak bagi tempat usaha tidak secara serta merta status HGB juga beralih hal tersebut harus dilakukan pelepasan hak sebagaimana diatur dalam Pasal 35 Peraturan Pemerintah Nomor 40 Tahun 1996 Hak Guna Usaha, Hak Guna Bangunan, Dan Hak Pakai Atas Tanah 
yaitu pada ayat 1 (c), dalam kasus yang penulis angkat status HGB diatas HPL kios Blok B dan C Pasar Pagi Kota Tegal pasca pemutusan kontrak bagi tempat usaha masih atas nama pihak Investor sebagai pemegang hak.

b. Perlindungan hukum bagi pihak ketiga/penyewa adalah bentuk perlindungan represif pertama yang tercermin didalam putusan keberatan Putusan Keberatan Nomor 7/Pdt.G.S/2018/PN.Tgl. Pengadilan Negeri Tegal gugatan dari investor yang dinyatakan tidak dapat diterima ada mengacu pelaksanaan perjanjian perdamaian antara Pihak Pemerintah Daerah Kota Tegal dengan Pihak Investor.

\section{Saran}

a. Perlu adanya peraturan yang mengatur hapusnya status HGB ketika putusnya Perjanjian/ Kontrak Bagi Tempat Usaha atau perjanjian sejenis mengenai pembangunan dan pengelolaan sebelum jangka waktunya berakhir, terlebih mengenai fasiltas publik seperti pasar.

b. Untuk mencegah dampak kepada pihak ketiga (penyewa) seharusnya Pemerintah Daerah Kota
Tegal adanya penyalahgunaan HGB yang belum dilepaskan oleh Pihak Investor, Pemerintah Daerah Kota Tegal mengajukan gugatan terhadap Pihak Investor yang telah tidak melaksankan perjanjian perdamaian yang disepakati.

\section{Daftar Pustaka}

Fuady, Munir, 2002, Kontrak Pemborongan Mega Proyek, PT Citra Aditya Bakti, Bandung

Fuady, Munir, 2001, Hukum Kontrak (Dari Sudut Padang Hukum Bisnis), PT Citra Aditya, Bandung Wahyudi Kumotoromo, 1999, Kemitraan Usaha Sebagai Alternatif Dalam Pembiayaan Sektor Publik Di Daerah:Argumentasi Teoretis dan

Wahyudi Kumotoromo, 1999, Kemitraan Usaha Sebagai Alternatif Dalam Pembiayaan Sektor Publik Di Daerah:Argumentasi Teoretis dan kasus kemitraan Pemerintah Swasta di Pemerintah Cirebodan Pemda Surakarta. diakses16 Januari 2019 tersedia di website https://www.researchgate.net/publica tion/277819096_Kemitraan_Usaha_ SeSwasta_di_Pemda_Cirebon_dan_ Pemda Surakarta/download

B.Resti Nuhayati dan Sudikno Mertokusumo, 1996, Tinjauan Yuridis Kontrak Bagi Tempat Usaha DI Propinsi Dati I Jawa Tengah, diakses $16 \quad$ Januari

2019tersediadiwebsitehttp://i lib.ugm.ac.id/jurnal//download.php?d atald $=5876$

Djauhari Dwi Heny Ratnawati, 2018, Jurnal Akta Vol 5 No 1 Maret: Pelaksanaan Akta Pelepasan Hak Sebagai Alas Hak Untuk Mengajukan Permohonan Peralihan Dan Perubahan Hak Guna Bangunan Yang Jangka Waktunya Telah Berakhir Di 
45 | Ju r n a | I d e a H u k u m

Vol. $6 \mathrm{No} .1 \mathrm{Maret} 2020$

Magister Hukum Universitas Jenderal Soedirman

Kabupaten Brebes

Subekti, 2003, Pokok-pokok Hukum Perdata, Intermasa, Jakarta.

Y Hikmat Ginanjar, 2005, Tesis:

Perjanjian Build Operate Transfer sebagai bentuk pilihan perjanjian yang paling menguntungkan pada perjanjian kerjasama antara pemerintah daerah kabupaten bogor dengan PT lestari Indah Raya Persada Dalam Pembangunan Serta Pengelolaan Pasar/ Sub Terminal Parung, Universitas Indonesia, Jakarta.

http://repository.uma.ac.id/bitstream/13 456789/1537/5/088400236 file5.pdf. bagai_Alternatif_Dalam_Pembiayaa n_Sektor_Publik__Di_Daerah_Argum entasi_Teoretis_dan_Kasus_Kemitra an_Pemerintah 